\title{
Shelf life of minimally processed pineapples treated with ascorbic and citric acids
}

\author{
Lucimara Rogéria Antoniolli ( $\left.{ }^{*}\right)$; Benedito Carlos Benedetti (2); Men de Sá Moreira de Souza Filho \\ (3); Deborah dos Santos Garruti (3); Maria de Fátima Borges ( ${ }^{3}$ ) \\ (') Empresa Brasileira de Pesquisa Agropecuária (Embrapa), CNPUV, Caixa Postal 130, 95700-000 Bento Gonçalves (RS), Brasil. \\ (2) UNICAMP, Faculdade de Engenharia Agrícola, Caixa Postal 6011, 13083-970 Campinas (SP), Brasil. \\ (3) Embrapa, CNPAT, Rua Dr. a Sara Mesquita, 2270, 60511-110 Fortaleza (CE), Brasil. \\ $\left(^{*}\right)$ Corresponding author: lucimara@cnpuv.embrapa.br
}

Received: Dec. 6, 2011; Accepted: June 28, 2012

\begin{abstract}
The purpose of this research was to determine the shelf life of minimally processed (MP) 'Pérola' pineapples treated with ascorbic acid (AA) and citric acid (CA) based on physical, chemical, sensorial and microbiological attributes. Slices were dipped into drinking water (control) or combined solutions of AA:CA (\%) (1.0:0.5 and 1.0:1.0) with sodium hypochlorite ( $\mathrm{NaClO} 20$ mg $\mathrm{L}^{-1}$ ) for 30 seconds. The samples were conditioned in polyethylene terephtalate packages and stored at $4 \pm 1{ }^{\circ} \mathrm{C}$ per 13 days. The low peroxidase activity in the slices treated with antioxidant combinations was related to low $\mathrm{pH}$ values observed in these samples. The treatments 1.0:0.5 and 1.0:1.0 (AA:CA, \%) favored maintenance of the initial $a^{*}$ values and avoided the pulp browning. The ascorbic acid increased more than double on the $2^{\text {nd }}$ day in the treated slices. By the $4^{\text {th }}$ day the $\mathrm{CO}_{2}$ values suggested a higher respiratory activity in the slices treated with anti-browning compounds. The antioxidant treatments did not produce detectable residual flavors in the MP pineapple. Regardless of microbiological safety during the 13 days of cold storage, the control slices can be kept by 6 days, afterwards the color and dehydration become strong enough to affect the appearance. On the other hand, MP 'Pérola' pineapples treated with 1.0:0.5 (AA:CA, \%) and $\mathrm{NaClO}\left(20 \mathrm{mg} \mathrm{L}^{-1}\right)$ can be stored for 8 days at $4 \pm 1^{\circ} \mathrm{C}$, which represents the extension of the shelf life in 2 days. After this period the overripe odor starts to develop.
\end{abstract}

Key words: Ananas comosus, minimal processing, enzymatic browning, residual flavor, microbiological safety.

\section{Vida útil de abacaxis minimamente processados tratados com ácido ascórbico e ácido cítrico}

\section{Resumo}

Procurou-se determinar a vida útil de abacaxis 'Pérola' minimamente processados (MP), tratados com ácido ascórbico (AA) e ácido cítrico ( $A C)$, com base nos atributos físicos, químicos, sensoriais e microbiológicos. As fatias foram imersas em água (controle) ou em soluções combinadas de AA:AC (\%) (1,0:0,5 e 1,0:1,0) com adição de hipoclorito de sódio ( $\mathrm{NaOCl} 20$ mg L-1), durante 30 segundos. As amostras foram acondicionadas em embalagens de polietileno tereftalato e mantidas à temperatura de $4 \pm 1{ }^{\circ} \mathrm{C}$ durante 13 dias. A baixa atividade da peroxidase nas fatias tratadas foi relacionada aos baixos valores de $\mathrm{pH}$ observados nessas amostras. Os tratamentos 1,0:0,5 e 1,0:1,0 (AA:AC, \%) favoreceram a manutenção dos valores iniciais de a* e evitaram o escurecimento da polpa. A concentração de ácido ascórbico aumentou mais que o dobro, no $2 .^{\circ}$ dia, nas fatias tratadas. Os valores de $\mathrm{CO}_{2}$ observados no $4 .^{\circ}$ dia sugeriram a ocorrência de maior atividade respiratória nas fatias tratadas com os compostos antioxidantes. Os tratamentos antioxidantes não produziram sabor e odor residuais no abacaxi MP. Apesar de comprovada a segurança microbiológica durante os 13 dias de armazenamento, as fatias-controle podem ser mantidas por seis dias, uma vez que o escurecimento e o aspecto desidratado prejudicam a aparência do produto após esse período. Abacaxis 'Pérola' MP tratados com 1.0:0.5 (AA:AC, \%) e NaOCl (20 mg L $\left.\mathrm{L}^{-1}\right)$ podem ser armazenados por 8 dias a $4 \pm 1{ }^{\circ} \mathrm{C}$, o que representa o prolongamento da vida útil em dois dias. Após esse período, o odor de sobremaduro começa a se desenvolver. Palavras-chave: Ananas comosus, processamento mínimo, escurecimento enzimático, sabor residual, segurança microbiológica.

\section{INTRODUCTION}

The supply of minimally processed (MP) products has been increased considerably in the late years. Frequently, however, the quality of such products is still unsatisfactory. Pineapples stand out among tropical fruits that have potential to be commercialized as a ready-to-eat product due to its sensorial quality and its morphological structure which makes the immediate consumption difficult. MP pineapple is widely commercialized, presenting nevertheless problems of conservation, like pulp browning. Due to cutting operations, a great number of cells are disrupted, which causes the release of enzymes and their substrates, promoting the increase of oxidative enzyme-catalyzed 
processes (Rolle and Chism, 1987). The main enzymes responsible for tissue browning in fruits are polyphenol oxidase (PPO) and peroxidase (POD) (GONÇALVES, 2000). DAs et al. (1997) did not observe polyphenol oxidase activity in pineapple juice. Likewise, BRITo et al. (2007) reported no PPO activity in homogenized pineapple pulp of Pérola, Smooth Cayenne and IAC Gomo-de-Mel cultivars. POD is involved in multiple deteriorative changes affecting flavor, texture, color and nutrition in processed fruits and vegetables. POD performs a more important role in the browning process than $\mathrm{PPO}$ in pineapples, as previously found in jicama roots (Aquino-Bolaños and Mercado-Silva, 2004).

The use of browning inhibitors in minimally processed products is restricted to compounds that neither contribute to toxicity risk nor interfere in flavor (SAPERS, 1993). Compounds used to inhibit browning include ascorbic acid (AA), which decreases $\mathrm{pH}$ and is a reducing agent. In addition, this agent is cheap and safe for human consumption (SAPERS, 1993). A more effective preservation of color can be achieved by using a combination of an antioxidant agent (e.g. AA) and an acidulant (e.g. citric acid, CA) (Sapers and Douglas, 1987; Laurila et al., 1998; Ahvenainen, 2000). Additionally, this kind of treatment can be considered a way to enrich fruit tissue in AA (Cocci et al., 2006). As reported by WeLLER et al. (1997), when slices of starfruit were treated in 1.0 or $2.5 \%$ CA and $0.25 \%$ AA solution, they presented less browning than the control samples. Combinations of ascorbic acid ( $0.5 \%$ to $1.0 \%)$ and citric acid ( $0.2 \%$ to $1.0 \%)$ have been described as efficient for preventing browning in minimally processed apple (ARTÉs et al., 1998).

The objective of this research was to determine the shelf life of minimally processed 'Pérola' pineapples treated with ascorbic and citric acids based on physical, chemical, sensorial and microbiological attributes.

\section{MATERIAL AND METHODS}

Pineapples (Ananas comosus L. Merril cv. Pérola) were harvested from a commercial field located in Touros (Rio Grande do Norte State, Northeast of Brazil). Fruit were selected according to the size and the skin color (fruits completely green and with a yellow fruitlet center, corresponding to stages 1 and 2 of the Classification Standards of Pineapples; CQH, 2003). The crowns were cut at about $30 \mathrm{~mm}$ from the fruit apical region. Fruit were washed with water and neutral detergent and disinfected with a $\mathrm{NaClO}$ solution $\left(200 \mathrm{mg} \mathrm{L}^{-1}\right)$ for $2 \mathrm{~min}$ (Antoniolli et al., 2005). Fruit were conditioned in washed and disinfected (200 $\mathrm{mg} \mathrm{L}^{-1} \mathrm{NaClO}$ solution) plastic boxes and kept at $12 \pm 1^{\circ} \mathrm{C}$ for approximately $24 \mathrm{~h}$. After that, they were mechanically peeled and manually sliced. The slices were cut at approximately $10 \mathrm{~mm}$ thickness and their cores were removed.

The slices were dipped in water (control) or different combined solutions of ascorbic acid and citric acid for 30 seconds.
Based on the preliminaries results, treatments consisted of the combinations 1.0:0.5 and 1.0:1.0 (AA:CA, \%). Both solutions, including control, had $\mathrm{NaClO} 20 \mathrm{mg} \mathrm{L}^{-1}$ added and they were kept at $10^{\circ} \mathrm{C}$. All the chemicals used were of analytical grade (Sigma Chemical Co.). The liquid excess was drained for $2 \mathrm{~min}$. The equipment and utensils were disinfected with $200 \mathrm{mg} \mathrm{L}^{-1} \mathrm{NaClO}$ solution to prevent crossed contamination. Disposable gloves, masks and head wear were used with the same intention. The processing was carried out in refrigerated conditions, with temperatures from 12 to $15^{\circ} \mathrm{C}$.

The pineapple slices were conditioned in polyethylene terephthalate (PET) packages previously sanitized with $\mathrm{NaClO}$ solution $\left(20 \mathrm{mg} \mathrm{L}^{-1}\right)$, and stored at $4 \pm 1{ }^{\circ} \mathrm{C}$ per 13 days. The PET packages were sealed by pressure.

Every two days, the fruits were evaluated regarding to a) $\mathrm{pH}$ : in the homogenized samples; b) peroxidase activity $\left(\mathrm{U} \mathrm{g}^{-1} \mathrm{~min}^{-1}\right)$ : determined according to the methodology of KHAN and Robinson (1994); c) pulp color: measured with a Minolta Chromameter (Model CR-300) in the CIE $\mathrm{L}^{*} \mathrm{a}^{*} \mathrm{~b}^{*}$ mode. Although there is a reference (GonZÁlez-Aguilar et al., 2004) for assessing pulp browning in minimally processed pineapples by analyzing $\mathrm{L}^{*}$ (lightness loss) and $\mathrm{b}^{*}$ (yellowness loss) parameters, the evaluation was carried out using the $\mathrm{L}^{*}$ and $\mathrm{a}^{*}$ parameters, which are recommended for apples (ARTÉs et al., 1998), since they were more efficient in detecting browning in preliminary assays; d) ascorbic acid content $\left(\mathrm{mg} 100 \mathrm{~g} \mathrm{~g}^{-1}\right)$ : determined according to CarvalHo et al. (1990). In addition, $\mathrm{CO}_{2}$ was measured along the storage period and consisted in conditioning slices in hermetically sealed containers $(1.5 \mathrm{~L})$, which were fitted with a rubber septum, allowing for headspace gas sampling. Gas samples were taken every day and injected in a gas chromatograph (CG DANI 86.10) fitted with TCD detector for $\mathrm{CO}_{2}$ and FID detector for ethylene. A Porapak N column was used with $4.0 \mathrm{~m}$ length and $3.175 \mathrm{~mm}$ diameter, operated at constant temperature of $60^{\circ} \mathrm{C}$. Hydrogen was used as carrier gas at a flow rate of $30 \mathrm{~mL} \mathrm{~min}{ }^{-1}$. Carbon dioxide was quantified by calibration with a standard of $5 \% \mathrm{CO}_{2}$.

The slices were evaluated for residual flavor after approximately 15 hours of storage at $4 \pm 1{ }^{\circ} \mathrm{C}$. The 'Difference-of-Control' test was carried out by a nontrained sensory panel with 30 assessors. This test is used to determine perceptive differences between each treatment and a standard (non-treated pineapple) (Ferreira et al., 2000). The presence of total $\left(35^{\circ} \mathrm{C}\right)$ and thermotolerant $\left(44.5\right.$ to $\left.45.5^{\circ} \mathrm{C}\right)$ coliforms in the fresh-cut pineapple was evaluated on day 0 (initial). Mesophilic aerobic, mold and yeast counts were made at $0,1,4,7,10$ and 13 days. Analyses were carried out according to the methodology described by Silva et al. (2007) and Downes and Ito (2001). Mesophilic aerobic, mold and yeast populations were expressed by $\log \mathrm{CFU} \mathrm{g}{ }^{-1}$.

The sensorial test was performed with the control and the best anti-browning treatment. The slices were 
evaluated at $1,4,6,8$ and 11 days, according to the main attributes that indicate loss quality in minimally processed pineapple: color (browning), translucency, dehydration appearance, and overripe odor and flavor. The assessment was performed by applying a descriptive analysis with a panel of 9 trained assessors to specifically evaluate the aforementioned attributes. The Quantitative Descriptive Analysis (QDA) provides a complete description and quantification of the sensory properties of a product, representing one of the most complete and sophisticated methods for characterizing important sensory attributes (STONE et al., 1974). A 9-cm non-structured hedonic scale was used.

All the experiments were performed in an entirely randomized design, and the interaction between treatment and time was evaluated with three replicates. Data was submitted to a variance analysis (ANOVA), and the means were compared through Tukey multiple range test at $p \leq 0.05$. The means obtained in the sensory analysis were analyzed using the Dunnet test, at $\mathrm{p} \leq 0.05$. The values of mesophilic aerobic, mold and yeast counts were transformed into $\log (\mathrm{x})$, submitted to a variance analysis (ANOVA) and the means were compared through Tukey multiple range test at $\mathrm{p} \leq 0.05$.

\section{RESULTS AND DISCUSSION}

\section{Physical, chemical, sensorial and microbiological parameters as indices to determine the best anti-browning treatment}

The $\mathrm{pH}$ values in the MP pineapples submitted to treatments 1.0:0.5 and 1.0:1.0 (AA:CA, \%) were statistically lower than the control, but no significant difference was detected between the antioxidant treatments (Figure 1a). Such results are in accordance to the previous data on higher $\mathrm{pH}$ in non-treated pineapple slices, as compared to the slices submitted to eight different combinations of ascorbic and citric acids, during 8 days at $4 \pm 1{ }^{\circ} \mathrm{C}$.
Independent of the treatment, the $\mathrm{pH}$ of the MP pineapple decreased during the 12 days of storage (Figure 1b). From the $6^{\text {th }}$ day on, the $\mathrm{pH}$ values were significantly lower than those observed at the beginning of the experiment (day 0 ), and reached 3.96 on the $12^{\text {th }}$ day of storage.

On the $2^{\text {nd }}$ and $6^{\text {th }}$ days of storage, the peroxidase activity of the MP pineapple treated with 1.0:0.5 (AA:CA, \%) was lower than that one of the control slices (Figure 2), but it did not differ from the MP treated with 1.0:1.0 (AA:CA, \%). The drastic decrease in peroxidase activity in the control fruit samples, which was observed on the $8^{\text {th }}$ day, narrowed the differences among the treatments and no significant difference was detected among the two treatments and the control. During the experimental period, the MP fruit samples submitted to the ascorbic and citric acid treatments tended to demonstrate little variation in peroxidase activity, and there was no difference during the entire evaluation period. The low peroxidase activity in the MP fruits treated with antioxidant combinations, which was observed mainly until the $6^{\text {th }}$ day, was possibly related to low $\mathrm{pH}$ values. According to Burnette (1977), acidification of peroxidase causes a pronounced change in the protein from the native state to the reversible denatured state. It is known there is an inherent gradient of maturation from the basal to apical area in the pineapple fruit (Dull, 1971) and an increase of the peroxidase solubility as a result of the fruit maturation advance (Mello and Clemente, 1996). Therefore, it is possible that the accentuated reduction in the peroxidase activity observed in the control, on the $8^{\text {th }}$ day, could be due to the ripening degree dissimilarity between these samples and the others in the experiment. According to BRITO et al. (2007), the peroxidase activities in the basal, medium and apical areas of the 'Pérola' pineapple were estimated as 6091, 5099, and $5683 \mathrm{U} \mathrm{g}^{-1}$, respectively.

The addition of ascorbic and citric acids did not affect the $\mathrm{L}^{*}$ color of the MP pineapple, which ranged from 61.91 to 66.05 for 12 days of storage (data not showed). In the control, there was a gradual increase in the $\mathrm{a}^{*} \mathrm{pa}-$ rameter of pulp color, reaching -0.09 on the $8^{\text {th }}$ day of

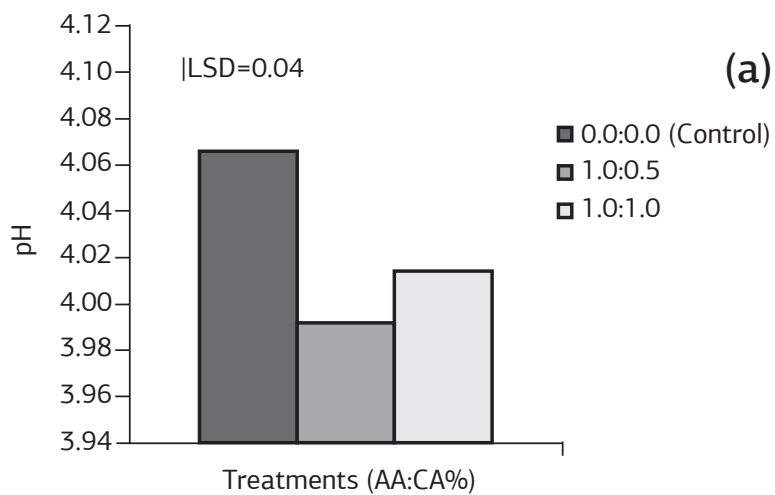

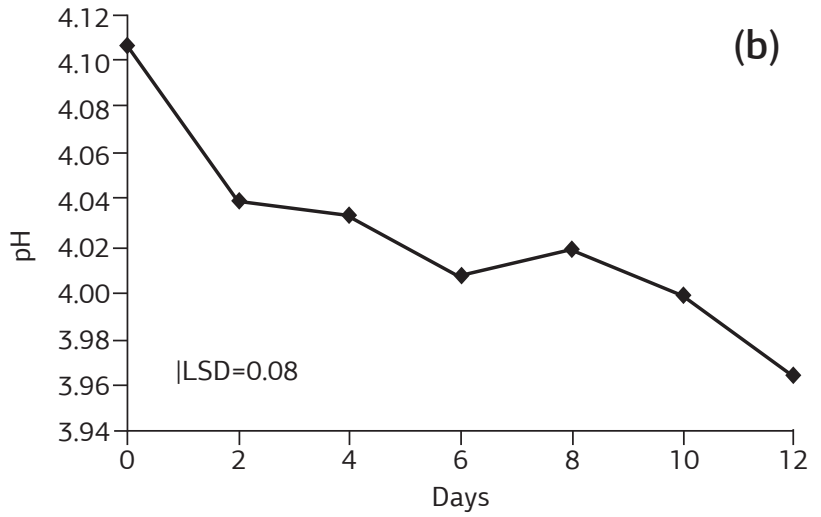

Figure 1. Values of $\mathrm{pH}$ in MP 'Pérola' pineapple treated with two combinations of ascorbic acid (AA) and citric acid (CA) (a), and stored at $4 \pm 1{ }^{\circ} \mathrm{C}$ for 12 days (b). LSD: Least Significant Difference $(\mathrm{p} \leq 0.05)$. 


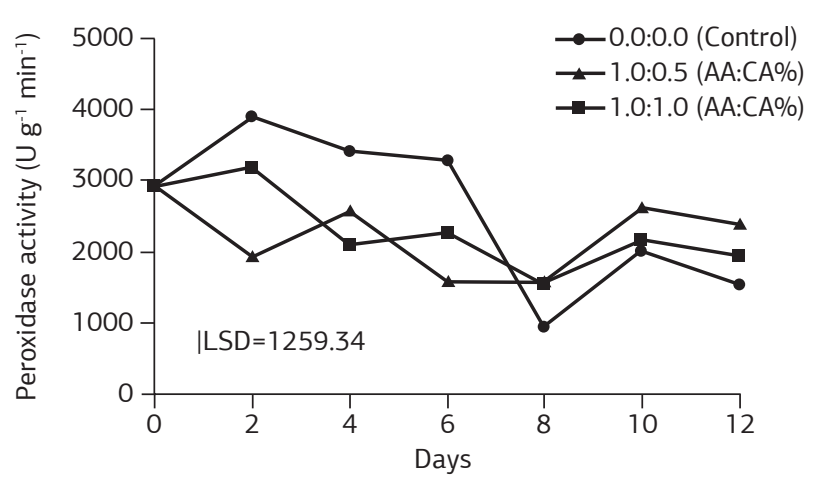

Figure 2. Peroxidase activity in MP 'Pérola' pineapple treated with two combinations of ascorbic acid (AA) and citric acid (CA), and stored at $4 \pm 1{ }^{\circ} \mathrm{C}$ for 12 days. LSD: Least Significant Difference $(\mathrm{p} \leq 0.05)$.

storage and, afterwards, remaining without significant changes. The chromatic coordinate $\mathrm{a}^{*}$ varies from negative values which indicate green to positive ones that indicate red/magenta. The changes observed in this coordinate in the non-treated slices may have contributed to brownish tones noticed in the sensorial test after 8 days of storage. During the entire evaluation period, the slices

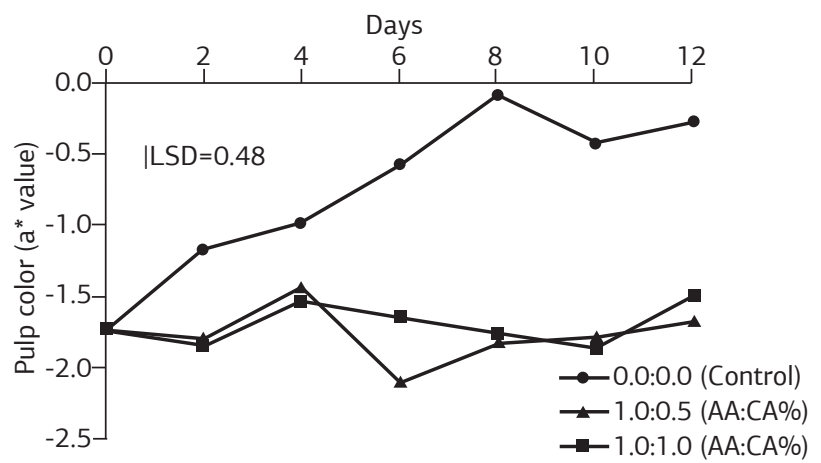

Figure 3. Fruit pulp color ( $\mathrm{a}^{*}$ value) of MP 'Pérola' pineapple treated with two combinations of ascorbic acid (AA) and citric acid (CA), and stored at $4 \pm 1{ }^{\circ} \mathrm{C}$ for 12 days. LSD: Least Significant Difference $(\mathrm{p} \leq 0.05)$.

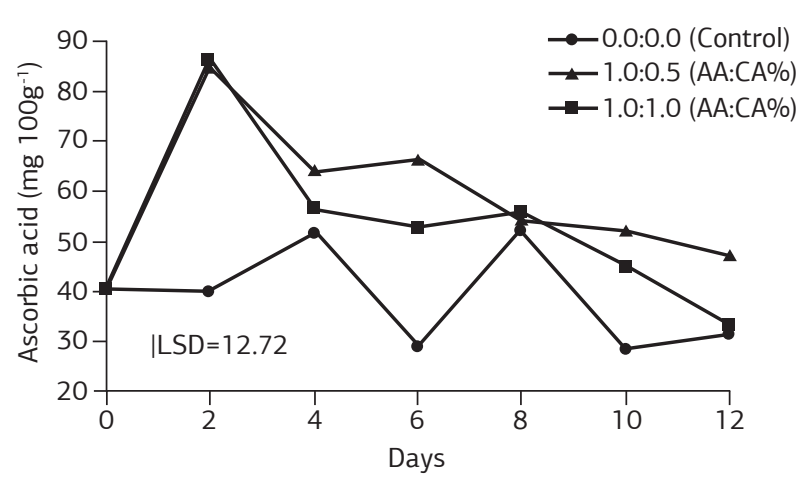

Figure 4. Ascorbic acid content in MP 'Pérola' pineapple treated with two combinations of ascorbic acid (AA) and citric acid (CA), and stored at $4 \pm 1^{\circ} \mathrm{C}$ for 12 days. LSD: Least Significant Difference $(\mathrm{p} \leq 0.05)$. treated with antioxidant combinations did not show significant differences between treatments (Figure 3). As previously observed, the treatments 1.0:0.5 and 1.0:1.0 (AA:CA, \%) favored maintenance of the initial a* values, therefore avoiding pulp browning during the entire evaluation period. Furthermore, SAPERS and Douglas (1987) and Coccr et al. (2006) verified an effective inhibition of browning in fresh-cut apples treated with solutions containing ascorbic and citric acids.

The non-treated MP pineapple showed the highest oscillations in ascorbic acid contents during the storage period. In the slices treated with antioxidants, the ascorbic acid increased more than double on the $2^{\text {nd }}$ day, and on the $4^{\text {th }}$ day it decreased to values that were statistically equal to the control. Thereafter, the decrease in ascorbic acid content continued in a moderate manner in the pineapple slices treated with 1.0:0.5 (AA:CA, \%), and it was significantly higher than that one of the control on the $10^{\text {th }}$ and $12^{\text {th }}$ days (Figure 4). The rapid increase in ascorbic acid at the beginning of storage was also observed by CarvalHo and Lima (2002) on MP kiwi treated with ascorbic acid solution (1\%). Cocci et al. (2006) observed that apple slices treated with 1.0:1.0 (AA:CA, \%) showed initial values of about 20 -fold higher than those of non-dipped slices, due to AA uptake as a result of the anti-browning treatment. Similarly, the values obtained by authors decreased after 1 day of storage (of $60-80 \%$ ). In spite of the decrease in ascorbic acid content in the treated slices, the anti-browning treatments promoted the enrichment of the fruit. In addition, Coccr et al. (2006) showed that the dipping of fresh-cut apples in a solution of 1.0:1.0 (AA:CA, \%) resulted in a detectable enriching effect in AA content until the sixth day of cold storage.

Until the $3^{\text {rd }}$ day of cold storage, there was no significant difference in the $\mathrm{CO}_{2}$ concentration, independent of the treatment (Figure 5). On the $3^{\text {rd }}$ day, the $\mathrm{CO}_{2}$ concentration started to increase quickly, and by the $4^{\text {th }}$ day it reached the highest values in the flasks containing slices treated with 1.0:1.0 (AA:CA, \%), followed by those treated

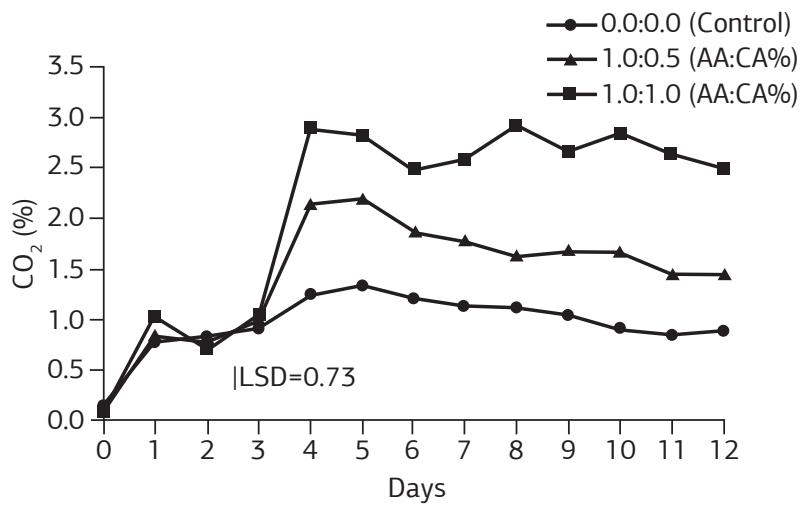

Figure 5. Concentration of $\mathrm{CO}_{2}(\%)$ inside flasks containing MP 'Pérola' pineapple treated with two combinations of ascorbic acid (AA) and citric acid (CA), and stored at $4 \pm 1{ }^{\circ} \mathrm{C}$ for 12 days. LSD: Least Significant Difference $(\mathrm{p} \leq 0.05)$. 
with 1.0:0.5 (AA:CA, \%) and by the control. Increased $\mathrm{CO}_{2}$ levels were maintained until the end of the cold storage. These results suggest a higher respiratory activity in slices treated with anti-browning compounds, which is in agreement with the reported higher metabolic activity in fresh-cut potatoes after application of citric and ascorbic acids (Rocculi et al., 2007). It is possible that the differences of metabolic activity between the two treatments were induced by the increase in citric acid concentration, considering that the ascorbic acid concentration was kept constant. These results indicate that the exogenous organic acids were absorbed by the plant tissues and, possibly, the imported citric acid affected the reactions of the tricarboxylic acid cycle (TCA), resulting in a respiratory increase.

In the sensory tests, no significant differences were observed between the treatments and the control, indicating that the antioxidant treatments 1.0:0.5, 1.0:1.0 (AA:CA, \%) did not produce detectable residual flavors in the minimally processed pineapple (Figure 6).

Total and thermotolerant coliforms were not detected in the pineapple samples evaluated at the beginning of the experiment (day 0 ), suggesting absence of these microorganisms in the raw material, and indicating the processing was performed in adequate hygienic-sanitary conditions. Endophytic population of mesophilic aerobic in the pineapple (day 0) was 4.65 $\log$ CFU g ${ }^{-1}$ and it showed a gradual increase in the first days of storage. On the $4^{\text {th }}$ day, these populations were estimated as $10^{6} \mathrm{CFU} \mathrm{g}^{-1}$ in the MP fruit samples submitted to diverse treatments, and no significant difference was detected among them (Figure 7). Similar responses were observed on the $7^{\text {th }}$ day, but the values were lower than the previous ones, and they were estimated as 5.34, 4.41, and $4.56 \log \mathrm{CFU}$ $\mathrm{g}^{-1}$ in slices treated with 1.0:0.5, 1.0:1.0 (AA:CA, \%) and in the control, respectively. The reduction can be attributed to adverse conditions of the environment, especially the $\mathrm{pH}$ reduction (Figure $1 \mathrm{~b}$ ) which, on the other hand, favored the increase of mold and

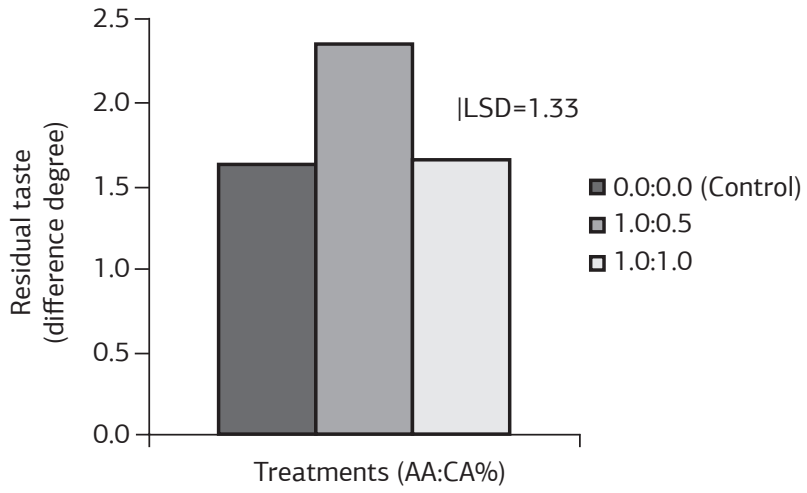

Figure 6. Residual taste in MP 'Pérola' pineapple resulting from treatments with two combinations of ascorbic acid (AA) and citric acid (CA). LSD: Least Significant Difference ( $\mathrm{p} \leq 0.05)$. yeast populations (Figure 8 ). On the $10^{\text {th }}$ day, the largest populations of mesophilic aerobic microorganisms were observed in the MP pineapple treated with 1.0:0.5 (AA:CA, \%), and the smallest populations were found in samples treated with 1.0:1.0 (AA: CA, \%). The control slices did not differ from both treatments. On the $13^{\text {th }}$ day of storage, no significant difference was detected in the microorganism populations of the two treatments and the control. In general, the endophytic populations of mesophilic aerobic microorganisms present in the MP pineapple were in a range of $10^{4}{\mathrm{e} 10^{6} \mathrm{CFU} \mathrm{g}}^{-1}$ during the entire evaluation period, and the largest populations were observed on the $4^{\text {th }}$ day of storage (Figure 7).

Variations in mold and yeast populations in the MP pineapple were not significant among the treatments. Estimates of these microorganism populations were in a range of $10^{3}$ to $10^{4} \mathrm{CFU} \mathrm{g}{ }^{-1}$, and no significant difference was detected during the 13 days of storage (Figure 8). Pinheiro et al. (2005) found mold and yeast populations from $2.7 \times 10^{2}$ to $1.9 \times 10^{7} \mathrm{CFU} \mathrm{g}^{-1}$ in samples of MP pineapple collected from supermarkets in Fortaleza, CE, Brazil.

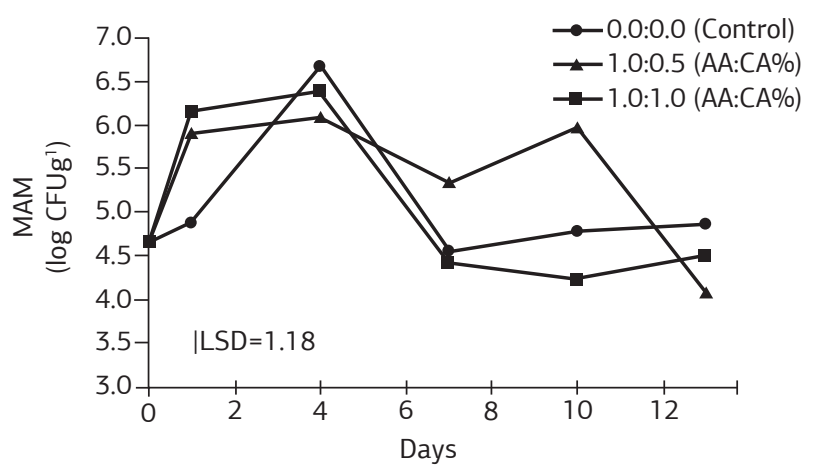

Figure 7. Mesophilic aerobic microorganisms (MAM) in MP 'Pérola' pineapple treated with two combinations of ascorbic acid (AA) and citric acid (CA), and stored at $4 \pm 1^{\circ} \mathrm{C}$ for 13 days. LSD: Least Significant Difference $(\mathrm{p} \leq 0.05)$.

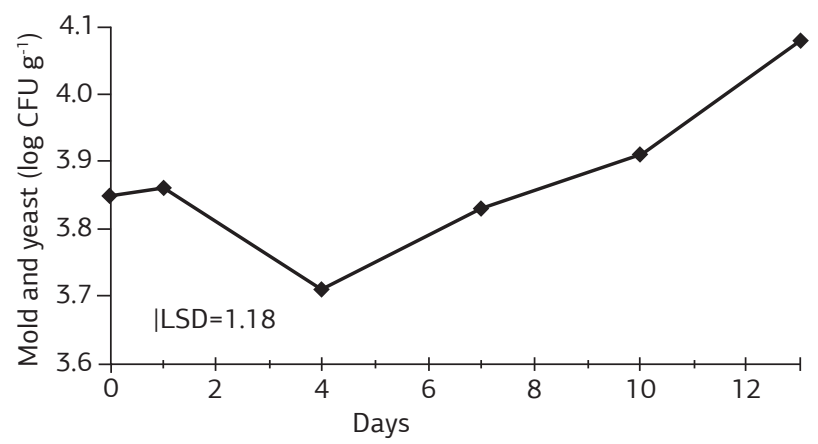

Figure 8. Mold and yeast populations in MP 'Pérola' pineapple, during 13 days at $4 \pm 1{ }^{\circ} \mathrm{C}$. LSD: Least Significant Difference $(\mathrm{p} \leq 0.05)$. 

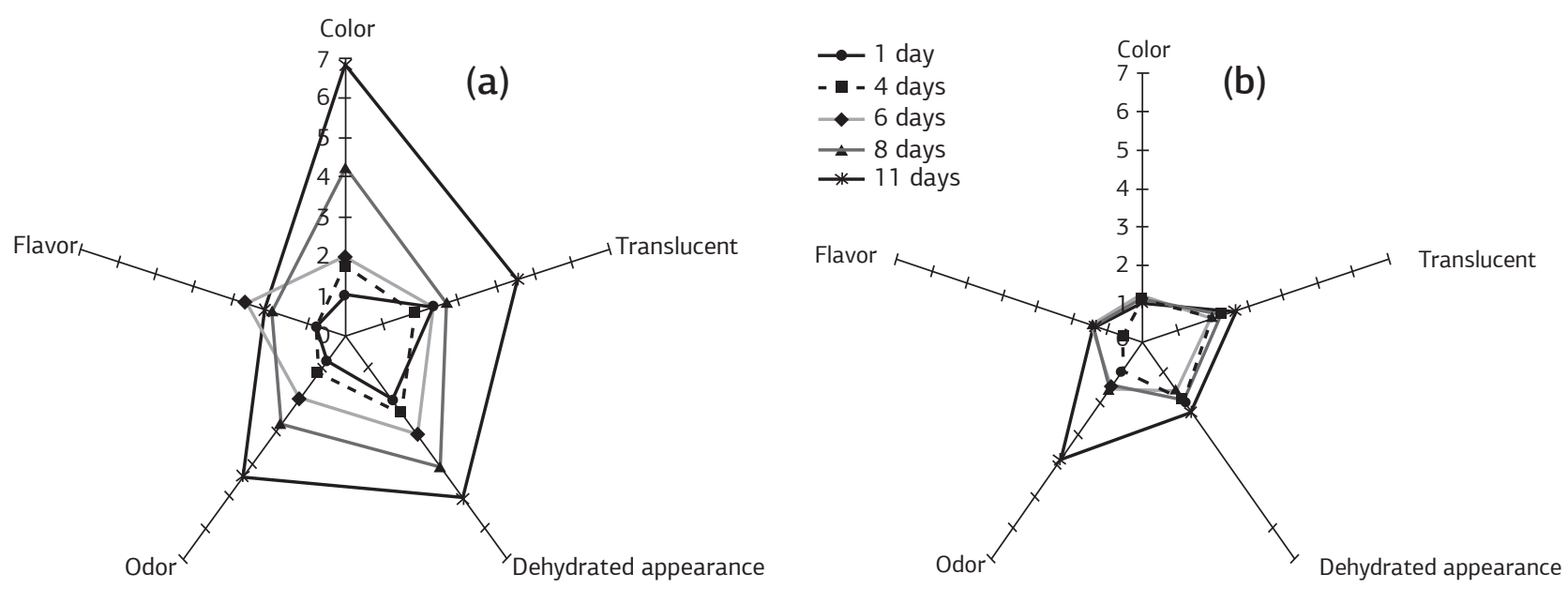

Figure 9. Descriptive analysis of MP 'Pérola' pineapple treated with two combinations of ascorbic acid (AA) and citric acid (CA), and stored at $4 \pm 1^{\circ} \mathrm{C}$ for 11 days. (a) Control (non-treated); (b) 1.0:0.5 (AA:AC, \%). (Mean values).

The main problem of fresh-cut pineapple is not microbiological decay (O'Connor-Shaw et al., 1994). It is possible the microflora of minimally processed fruit originates from within fruit tissue as a result of preharvest contamination (Antoniolli et al., 2005). Actually, Martínez-Ferrer and Harper (2005) stated that minimally processed fruit carry their natural microflora and may have about $10^{4}-10^{5} \mathrm{CFU} \mathrm{g}{ }^{-1}$.

In general, the ascorbic and citric acids did not affect the population growth rates of mesophilic aerobic, molds and yeasts. The little changes in these populations were possibly related to the efficiency of the whole fruit sanitization and the addition of $\mathrm{NaClO}\left(20 \mathrm{mg} \mathrm{L}^{-1}\right)$ to the solutions used for the immersion of MP pineapples.

\section{Sensorial parameters as indices to determine shelf life of minimally processed pineapples treated with the best anti- browning treatment}

Based on the obtained results, the lowest concentration of antioxidant compounds was chosen for determining the shelf life of the MP 'Pérola' pineapple, on the basis of a descriptive analysis of the sensory attributes of quality. It was considered that an additive, even if natural, should be used in a level that guarantees the preservation of fruit original characteristics.

As shown in the sensory profile of the non-treated slices, color was the most changed attribute (4.2), followed by the dehydrated appearance (4.1), odor (2.8), translucency (2.7), and flavor (2.0), which were more evident on the $8^{\text {th }}$ day and afterwards. At the end of the storage, it was observed that the alterations in color (6.8) and in dehydrated appearance (5.1) prevailed over translucency (4.6) and odor (4.4) alterations. The levels of overripe pineapple flavor remained similar to those observed on the $8^{\text {th }}$ evaluation day (Figure $\left.9 \mathrm{a}\right)$. In the slices treated with 1.0:0.5 (AA:CA, \%), alterations of these attributes were approximately 2.0 , on the scale, and they remained practically imperceptible until the $8^{\text {th }}$ day. On the $11^{\text {th }}$ day of 1.0:0.5 (AA:CA, \%) treatment, the odor was the most altered attribute (3.8), however, it was lower than the control (Figure 9b). Spanier et al. (1998) examined the effect of cold storage $\left(4^{\circ} \mathrm{C}\right)$ on the flavor volatile profile of fresh-cut pineapples and found that unpleasant odors and volatiles such as fermented, cheesy, sour dough, alcohol, and oily showed dramatic increases and masked the more desirable pineapple flavor.

Regardless of microbiological safety during the 13 days of cold storage, the control slices can be kept by 6 days, afterwards the color and dehydration become strong enough to affect the appearance. On the other hand, minimally processed pineapples treated with antioxidants should have their shelf life restricted to 8 days, because after this period the overripe odor starts to develop.

\section{CONCLUSION}

Minimally processed 'Pérola' pineapple submitted to immersion treatment in 1.0:0.5 (AA:CA, \%) with $\mathrm{NaClO}$ $\left(20 \mathrm{mg} \mathrm{L}^{-1}\right)$ can be stored for 8 days at $4 \pm 1^{\circ} \mathrm{C}$, which represents the extension of the shelf life in 2 days.

\section{ACKNOWLEDGEMENTS}

This research received financial support from the Fundaçáo de Amparo à Pesquisa do Estado de São Paulo (FAPESP) - Brazil and Prodetab / World Bank. The authors thank Claísa A. Silva de Freitas for her technical contributions to this research. 


\section{REFERENCES}

AHVENAINEN, R. Minimal processing of fresh produce. In: ALZAMORA, S.M.; LOPEZ-MALO, A.; TAPIA, M.S. (Ed.) Minimally Processed Fruits and Vegetables. Gaithersburg: Aspen Publisher, 2000. p.277-290.

ANTONIOLLI, L.R.; BENEDETTI, B.C.; SOUZA FILHO, M.S.M.; BORGES, M.F. Effect of sodium hypochlorite on the microflora of fresh-cut 'Pérola' pineapple. Revista Brasileira de Fruticultura, v.27, p.157-160, 2005.

AQUINO-BOLAÑOS, E.N.; MERCADO-SILVA, E. Effects of polyphenol oxidase and peroxidase activity, phenolics and lignin content on the browning of cut jicama. Postharvest Biology and Technology, v.33, p.275-283, 2004.

ARTÉS, F.; CASTAÑER, M.; GIL, M.I. Review: Enzymatic browning in minimally processed fruit and vegetables. Food Science and Technology International, v.4, p.377-389, 1998.

BRITO, C.A.K.; SATO, H.H.; SPIRONELLO, A.; SIQUEIRA, W.J. IAC Gomo-de-mel pineapple (Ananas comosus (L.) Merrill): characteristics of pulp and peroxidase of juice. Boletim do Centro de Pesquisa de Processamento de Alimentos, v.25, p.257-266, 2007.

BURNETTE, F. Peroxidase and its relationship to food flavor and quality: a review. Journal of Food Science, v.42, p.1-6, 1977.

CARVALHO, A.V.; LIMA, L.C.O. Quality of kiwis minimally processed and treated with ascorbic acid, citric acid and calcium chloride. Pesquisa Agropecuária Brasileira, v.37, p.679-685, 2002.

CARVALHO, C.R.L.; MANTOVANI, D.M.B.; CARVALHO, P.R.N.; MORAES, R.M.M. Chemical analysis of foods. Campinas: Instituto de Tecnologia de Alimentos, 1990. 121p. (Technical Manual)

CENTRO DE QUALIDADE EM HORTICULTURA. Brazilian Program for the Modernization of Horticulture-Classification Standards of Pineapples. São Paulo: Centro de Qualidade em Horticultura, 2003.

COCCI, E.; ROCCULI, P.; ROMANI, S.; ROSA, M.D. Changes in nutritional properties of minimally processed apples during storage. Postharvest Biology and Technology, v.39, p.265-271, 2006.

DAS, J.R.; BHAT, S.G.; GOWDA, L.R. Purification and characterization of a polyphenol oxidase from the kew cultivar of Indian pineapple fruit. Journal of Agricultural and Food Chemistry, v.45, p.2031-2035, 1997.

DOWNES, F.P.; ITO, K. Compendium of methods for the microbiological examination of foods. Washington: American Public Health Association - APHA, 2001. 676p.

DULL, G.G. The pineapple: general. In: HULME, A.C. (Ed.). The biochemistry of fruits and their products. London: Academic Press, 1971. p.303-325.

FERREIRA, V.L.P.; ALMEIDA, T.C.A.; PETTINELLI, M.L.C.; SILVA, M.A.A.P.; CHAVES, J.B.P.; BARBOSA, E.M.M. Sensory Analysis: discriminative and affective tests. Campinas: Sociedade Brasileira de Ciência e Tecnologia de Alimentos, 2000. 127p.

GONÇALVES, N.B. Pineapple: postharvest. Brasília: EmbrapaSCT, 2000. 45p.
GONZÁLEZ-AGUILAR; G.A.; RUIZ-CRUZ, S.; CRUZVALENZUELA, R;;ODRÍGUEZ-FÉLIX,A.; WANG,C.Y.Physiological and quality changes of fresh-cut pineapple treated with antibrowning agents. Lebensmittel-Wissenschaft und-Technologie, v.37, p.369-376, 2004.

KHAN, A.A.; ROBINSON, D.S. Hydrogen donor specifity of mango isoperoxidases. Food Chemistry, v.49, p.407-410, 1994.

LAURILA, E.; KERVINEN, R.; AHVENAINEN, R. The inhibition of enzymatic browning in minimally processed vegetables and fruits. Postharvest News and Information, v.4, p.53-66, 1998.

MARTÍNEZ-FERRER, M.; HARPER, C. Reduction in microbial growth and improvement of storage quality in fresh-cut pineapple after methyl jasmonate treatment. Journal of Food Quality, v.28, p.3-12, 2005.

MELLO, E.T.; CLEMENTE, E. Thermostability of crude extract of peroxidase from pineapple. Revista Unimar, v.18, p.757-763, 1996.

O'CONNOR-SHAW, R.E.; ROBERTS, R.; FORD, A.L.; NOTTINGHAM, S.M. Shelf life of minimally processed honeydew, kiwifruit, papaya, pineapple and cantaloupe. Journal of Food Science, v.59, p.1202-1206, 1215, 1994.

PINHEIRO, N.M.S.; FIGUEIREDO, E.A.T.; FIGUEIREDO, R.W.; MAIA, G.A SOUZA, P.H.M. Evaluation of microbiological quality of fruits minimally processed commercialized in supermarkets in Fortaleza. Revista Brasileira de Fruticultura, v.27, p.153-156, 2005.

ROCCULI, P.; GALINDO, F.G.; MENDOZA, F.; WADSÖ, L.; ROMANI, S.; ROSA, M.D.; SJÖHOLM, I. Effects of the application of anti-browning substances on the metabolic activity and sugar composition of fresh-cut potatoes. Postharvest Biology and Technology, v.43, p.151-157, 2007.

ROLLE, R.S.; CHISM, G.W. III - Physiological consequences of minimally processed fruits and vegetables. Journal of Food Quality, v.10, p.157-177, 1987.

SAPERS, G.M. Browning of foods: control by sulfites, antioxidants and other means. Food Technology, v.47, p.75-84, 1993.

SAPERS, G.M.; DOUGLAS, F.W. Measurement of enzymatic browning at cut surfaces and in juice of raw apple and pear fruit. Journal of Food Science, v.52, p.1258-1262, 1987.

SILVA, N.; JUNQUEIRA, V.C.A.; SILVEIRA, N.F.A.; TANIWAKI, M.H.; SANTOS, R.F.S.; GOMES, R.A.R. Manual of methods for microbiological analysis of food. São Paulo: Varella, 2007. 536p.

SPANIER, A.M.; FLORES, M.; JAMES, C.; LASATER, J.; LLOYD, S.; MILLER, J.A. Fresh-cut pineapple (Ananas sp.) flavor. Effect of storage. In: CONTIS, E.T.; HO, C.T.; MUSSINAN, C.J.; PARLIMENT, T.H.; SHAIDI, F.; SPANIER, A.M. (Ed.) Food flavors: formation, analysis and packaging influences. Amsterdam: Elsevier Science B.V., 1998. p.331-343.

STONE, H.; SIDEL, J.L.; OLIVER, S.; WOOSLEY, A.; SINGLETON, R.C. Sensory evaluation by quantitative descriptive analysis. Food Technology, v.28, p.24-34, 1974.

WELLER, A., SIMS, C.A., MATTHEUWS, R.F., BATES, R.P., BRECHT, J.K. Browning susceptibility and changes in composition during storage of carambola slices. Journal of Food Technology, v.62, p.256-260, 1997. 